\title{
The (Formal) Exclusiveness of Julius Zeyer's Literary Language
}

\section{K (formální) exkluzivitě literárního jazyka Julia Zeyera}

\author{
Martin Schacherl \\ (České Budějovice, Czech Republic)
}

\begin{abstract}
:
The paper is focused on identifying the principal signs of formal exclusiveness that denote Julius Zeyer's literary language, precisely, his prose. Julius Zeyer wrote his prosaic works in standard Czech, deliberately differing from the contemporary usage, both common and neutral. The language used in his prosaic writings basically corresponded with the historicising concept of contemporary linguistics as recommended by language handbooks in the period. At all levels of usage, his prose presents numerous linguistic means which, even at that time, were considered mannered. Mannerism is thus understood as hypercorrect expression recommended for highly official communication, to which Zeyer's idiolect, many times insecure, submitted in literary creations and which probably suited his idea of the aim and purpose of the artist's work.
\end{abstract}

\section{Key words:}

Julius Zeyer; prose; style; linguistics; archaic; bookish

\section{Abstrakt:}

Cílem př́spěvku je identifikace principiálních znaků formální exkluzivity literárního jazyka Julia Zeyera, konkrétně jeho prózy. Julius Zeyer psal svá prozaická díla spisovným jazykem, vědomě odlišným od dobového lidového, ale i neutrálního jazyka. Jazyk jeho prozaických děl v podstatě odpovídal historizující koncepci tehdejší jazykovědy, jak ji představovala doporučení dobových jazykových příruček. $V$ jeho próze najdeme četné jazykové prostředky všech jazykových rovin, které byly hodnoceny i ve své 
době jako strojené. Strojenost je zde chápána ve smyslu vybraného hyperkorektního vyjadřování pro vysoce oficiální ráz komunikace, kterému se mnohdy nejistý Zeyerův idiolekt v literární práci podřizoval a který pravděpodobně vyhovoval básníkově představě o poslání a smyslu umělecké práce.

\section{Klíčová slova:}

Julius Zeyer; próza; styl; jazykověda; archaičnost; knižnost

The paper is focused on identifying the principal signs of formal exclusiveness that denote Julius Zeyer's literary language, precisely, his prose. Julius Zeyer (1841-1901) maintains a secure position in the golden fund of Czech literary classics, his name being widely known, though a closer intimacy with the author rather develops from the knowledge of attributes associated with his attitude to life as a solitary poet, unclassifiable and undiscernible, exceptional, almost a cultic figure. No doubt the formal unconformity of Zeyer's language within the context of Czech literature has always attracted the interest of literary scholars. There were many linguistic and literary studies, especially in the the first half of the 2oth century, endavouring to denote the excentricity of his language. His "exceedingly peculiar style" was in general either uncritically celebrated or condemned. ${ }^{1}$ If we overlook the limits of the linguistic competence of the poet himself and the impact of editorial alterations of his texts, the formal extrinsicality of Zeyer's literary idiom consists in the co-agency of a number of attributes: namely, the archaic and bookish tone of his intentionally hyperstandard diction; the idiosyncratic type of a long narrative sentence; the distinctive textual rhythmicity linked with exuberantly decorative lexical imagery.

The language of Julius Zeyer's prosaic works, with the exception of a few minor points, fully complied with the requirements of Czech puristic manuals published between the 1870 s-1890s by the Matice česká committee and other authors. Zeyer's literary language remains, in this sense, a conspicuously standard variety, featuring numerous archaic linguistic elements, even with regard to the contemporary usage. To certain extent, the poet's narratives may have been loaded with obsolete linguistic elements through external agents, such as editorial interventions or acceptance of the suggestions and models commended by reputable linguistic pundits. The texts, save negligible exceptions, were first published in magazines, and later, in a book form. The differences between both variations ensued from the author's more demanding attitude to book editions than to magazines where much was cancelled by the editor, e.g.

1 SCHACHERL, M.: Zeyer vypravěč. Vybrané rysy stylu prozaických prací fulia Zeyera. České Budějovice: PF JU 2013. 
politically dangerous and improper topics at the time. Anyway, editorial interferences penetrated into the book editions of Zeyer's texts just as well. ${ }^{2}$ Notorious here is Zeyer's conciliatory attitude to editorial interceptions prescribed by the contemporary Matice puristic manuals. ${ }^{3}$ No less important is the argument that the language norm in the latter half of the 19th century cannot be deemed but fairly questionable.

In Zeyer, however, it was not solely deference to purists but in all likelihood the authorial intention, i.e. a deliberate endeavour to use standard literary expression. His intentional effort to exploit standard language was (probably) a natural outcome of fulfilling a desired communicational objective of his creations, in correspondence with the generational concept of the purpose and mission of art on its own. The bookish character of his speech, linked with marked archaicism, even within the contemporary usage, preconditioned the poet's purposeful professing the aesthetic function, which, among others, manifested itself in the artificialness of his expression. All the same, the bookishness and archaic stamp of Zeyer's language does not consist in phonology or morphology, where the capacities are distinctly limited, yet in vocabulary or syntax, in particular. It is the archaic vein, namely of the syntactic structure, that Zeyer's style shared e.g. with K. Světlá's diction, i.e. with the preceding, in many ways contrasting, Máj affiliated generation. What most differentiated Zeyer's literary idiom from the previous literary grouping was its pronounced artistic character. Consequently, the formal linguistic exclusiveness of the prosaic writing of the new cosmopolitan generation became the most prominent feature of Julius Zeyer's works.

The exceptionality of J. Zeyer's linguistic imagination is aided by an abundance of language amassment devices. Specific means of the accoustic arrangement of his sentence, involving various types of repetition, are a very frequent marked occurrence in his prose and belong to the most striking instruments of his linguistic enhancement. The high incidence of speech figures in his prose diverts attention from the communicational content, leaving it with its expressional component. Thus the noteworthy rhythmicity of Zeyer's fiction does not only result from the distinction and organisation of sound elements in a sentence, or from the balanced sentence structure, it is also the consequence of specific sentence arrangement with multiform repetitions intermingling at the phonetic, as well as grammatical, lexical and semantic levels. The quantitative figures conformed to the poet's strange and intense urge for communication, which accompanied his fixed opinions about his own personal limits, while reflecting and fulfilling his inner needs for appropriate self-expression. At the same time, their ostentatious artistic expressiveness and aesthetic ambition

2 HAUSENBLAS, O.: Poznámka editora. In: ZEYER, J.: Tři legendy o krucifixu a jiné básně. Praha: Československý spisovatel 1987, p. 278.

3 STICH, A.: Ediční poznámka. In: ZEYER, J.: Epické zpěvy. Praha: Československý spisovatel, 1988, p. 246. 
demonstrate Zeyer's endeavour to differentiate between the language used in a work of art and the language of common communication. The unifying perspective is probably the empiric author's attempt to use a denomination with a more expressive and persuasive function. In this sense, Zeyer's prose language reveals noticeable features of the Art Nouveau style. If the standard and bookish, even archaic, traits of his language related Zeyer to the poetic generation headed by Jan Neruda (1834-1891), then the linguistic figures produced by assembling the language material rank among the devices that manifestly do not go beyond the generational context of only two successive literary groupings, but, taking account of their extent in his narratives, beyond the entire Czech literary production at the time. ${ }^{4}$

A lion's share in the formation of Zeyer's specific narrative sentence pattern have linguistic enumerations. The basic principles behind Zeyer's word order are phonetic and semantic motives. Thus the position of expressions in a sentence is also determined by the functional sentence perspective, i.e. by their contextual connectivity or unconnectivity. In Zeyer, the contextually conjuncted members as a rule appear at the beginning, while those contextually disjuncted occur at the end of an utterance. The syntactic structure of Zeyer's compound sentence with prevailing parataxis surprisingly evokes certain conformance between his sentence and the principles of common speech. More often than not, Zeyer uses larger syntactic units rather than words. His notions, ideas, images are unexceptionally conveyed by whole syntagmata or long sentences, potentially, by word groupings. The authorial intention behind the speech syntax may have been restricted by the poet's language competence. Zeyer's unique, linguistically distinctive style descended from the fairly wavering individual usage of a writer who lacked systematic instruction in the Czech language and who all his life failed to benefit from the secure guidance of the Czech (standard) language in its stylistic diversity. With non-existent elementary codifying manuals, the instability of Zeyer's idiolect, which was not singly limited to the literary Czech language, thus reflected the discrepances in contemporary Czech usage and the poet's grasp of practical mother tongue. Zeyer's exclusively individual authorial style, intently different from the common speech, combines stylistically marked bookish and archaic elements, while in the syntactic structure, paradoxically, it also contains factual traces of common speech. Zeyer's peculiar style, whether intentionally or unintentionally heterogenous in expression, probably reflects both the authorial purpose of the standard utterance and the linguistic limitations of the empirically inclined author.

4 Nonetheless, it is difficult to define the functions of the specific phonetic arrangement of Zeyer's sentence based on repeating an expression. It is affected namely by euphonism, intensiveness, semantic aspects, by the inclination to dynamise tension or by tendencies to forceful phonetic enhancement of the intonation line of the poet's sentence, mainly consisting in the anaphoric or epiphoric repetition of a particular linguistic device. 
Zeyer's unparalleled language style emerges, to a large extent, from the idiosyncratic arrangement of the long epic sentence, in his prosaic writings dominated by the attribute and the simile. In most cases, the attribute comprises independent sentence members set apart and jointly with attached supplemental sentence members which take a significant share in the syntactic exuberance and intricate rhythmical patterning of his long narrative sentence. The poeticity of Zeyer's text, i.e. its dissimilarity from the neutral standard languge, or perhaps colloquial language, is strongly signalised by such devices as inverted word order. The high occurrence of the postpositioned unexpanded attribute is in Zeyer predominantly motivated by communicational factors. Through putting emphasis on the quality, the attribute becomes the intonational centre of the utterance, and, not infrequently, the last accentuated member; from the functional sentence perspective, it turns into the rheme. The result is Zeyer's original type of sentence where the quality emerges as the rheme. Within the word order inversions of the first type, there is a frequent incidence of the postponed attribute featuring another expanding sentence member between the attribute and the noun. A frequent occurrence in Zeyer's narrative is the unexpanded attributive adjective moved further from the noun directly subordinating this attribute though preceding it. In the second type inversion, Zeyer often separates the adjective from the noun in the 'interpositional sequence of expanded attributes'. The highest incidence of two inco-ordinate attributive adjectives is found in the position before the noun. The marked word order and sentence sequence comprise one of the most prominent stylistic characteristics, typical of the peculiar poeticity of Zeyer's idiom, as percieved by the contemporary readers and even more intensely by the modern readership.

A substantial contribution to Zeyer's idiosyncratic sentence structure based on long narrative sentences, and to the formal exclusivity of his style as well, is made by the simile. Like the attributive adjective, the simile represents a frequently occurrent device for enhancing Zeyer's individual prose style, even regardless its function. In overwhelming majority, Zeyer's similes are fixed metaphors, often both in form and in the presented resemblance, usually metaphorical. The simile is mostly based on an unsurprising metaphoric relation, in most cases figuratively denoting a typical feature of the compared subject. The aesthetic effect of such comparison does not result from an amazingly new appellation of reality, rather it ensues from a rediscovered metaphorical link, rich and emotionally enhanced as it may be. Its continuous gradual repetition or subsequent addition of individual attributes of the described similarity constitute syntactically intricate visual images. To Zeyer, the basic metaphorical relation is only the initial phase for evoking variously extended ultimate image of the presented semblance relation. The richness and profusion of Zeyer's imagery constitutes the basic aesthetic value of his simile, whose sensorial efficasy is indispensable for the 
sophisticated perception of the author's poetical style. The most important motivic source of Zeyer's similes is common speech. The repeated models of Zeyer's similes used in his narratives and in his personal correspondence may induce temptation to parallel some of the above mentioned authorial habits linked with expressing similarity to the natural means of his individual style, regardless of the textual function. Comparing the expressions of similarity in his works and in his correspondence may underline the absolute consistency of Zeyer's attitude to life in his symptomatic stylisation, here conveyed through one of the enhanced devices of his diction.

Julius Zeyer wrote his prosaic works in standard Czech, deliberately differing from the contemporary usage, both common and neutral. The language used in his prosaic writings basically corresponded with the historicising concept of contemporary linguistics as recommended by language handbooks in the period. At all levels of usage, his prose presents numerous linguistic means which, even at that time, were considered mannered. Mannerism is thus understood as hypercorrect expression recommended for highly official communication, to which Zeyer's idiolect, many times insecure, submitted in literary creations and which probably suited his idea of the aim and purpose of the artist's work.

The intentional diversity of the linguistic (as well as thematic) content of Julius Zeyer's prose significantly supplements the specific attitude to life maintained by a poet absolutely identified with the role of an exceptional and detached aesthete, creating a solid combination of successful, and in its complexity genuine, disengement and stylisation in the poet's life and creations. In regard to art and artistic activities, Zeyer remained uncompromising, consistent and thus genuine. His individual style, so incomprehensible today, remains to be successful because of its unreservedness and because it produced a complete unity with his attitudes, opinions and creations. Consequently, in Czech literature the life and literary works of Julius Zeyer represent a unique entity, perpetually provoking new interpretations and confrontations over the etablished legacy as it was created by his contemporaries and passed on by many other generations of recipients.

Today's readers, perceiving the poet's (literary) language at a distance of more than one hundred years, find it more bookish, archaic and exclusive than its contemporary readers did in the latter half of the 19th century. The formal eccentricity of Zeyer's style penalises his works including unquestionable, time honoured texts along with stories placed close the conventional books of adventure, so popular with present-day readership, even within the required reading. Modern readers, not only the young ones, find Zeyer's intricate syntax with a multitude of Germanisms, the exuberantly decorative imagery of his lexis, and the itemised diction fairly difficult to read, and due to their everyday linguistic practice, it is little wonder they are discouraged from reading his fiction by the poet's oddness. 


\section{References:}

BARTOŠ, F.: Nová rukovět správné češtiny. Telč: Nákladem Emila Štolce, 1901.

ČECHOVÁ, M. - KRČMOVÁ, M. - MINÁŘOVÁ, E.: Současná stylistika. Praha: Lidové noviny, 2008. ISBN 978-80-7106-961-4.

ČERMÁK, F.: Česká přirovnání. Slovník české frazeologie a idiomatiky - přirovnání. Praha: Academia, 1983. ISBN 978-80-7335-215-8.

HAUSENBLAS, O.: Poznámka editora. In: ZEYER, J.: Třri legendy o krucifixu a jiné básně. Praha: Československý spisovatel 1987, p. 278-281.

HAVRÁNEK, B. - ŠMILAUER, V. - ZÍSKAL, A.: Přiruční slovník jazyka českého (I-IX). Praha: Státní nakladatelství (1935-1957).

Komise širším sborem Matice české zřízená: Brus jazyka českého. Praha: Nákladem Theodora Mourka, 1877.

MAŠÍN, J.: Slovník českých vazeb a rčení. Praha: Nákladem vlastním. Úřednická tiskárna, 1916.

SCHACHERL, M.: Zeyer vypravěč. Vybrané rysy stylu prozaických prací Julia Zeyera. České Budějovice: PF JU 2013. ISBN 978-80-7394-428-5.

STICH, A.: Ediční poznámka. In: ZEYER, J.: Epické zpěvy. Praha: Československý spisovatel, 1988, p. 246.

TOMEK, V. V.: Krátká mluvnice česká pro Čechy. Praha: Nákladem Bedřicha Tempského, 1860.

\section{About the author}

\section{Martin Schacherl}

University of South Bohemia in České Budějovice, Faculty of Education, Department of Slavonic Languages and Literatures, České Budějovice, Czech Republic schacherl@pf.jcu.cz

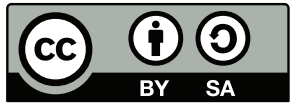

This work can be used in accordance with the Creative Commons BY-SA 4.0 International license terms and conditions (<https://creativecommons.org/licenses/by-sa/4.0/legalcode>). This does not apply to works or elements (such as images or photographs) that are used in the work under a contractual license or exception or limitation to relevant rights. 
